\title{
PELATIHAN PEMANFAATAN TEKNOLOGI KEUANGAN PADA KOPERASI BATIK TULIS KEBON INDAH KECAMATAN BAYAT, KLATEN
}

\author{
Yohan Wismantoro ${ }^{1}$ \\ ${ }^{1}$ Fakultas Ekonomi dan Bisnis Universitas Dian Nuswantoro \\ Jl. Nakula I / 5-11 Semarang \\ e-mail: ${ }^{1}$ yohan.wismantoro@dsn.dinus.ac.id
}

\begin{abstract}
Abstrak
Peran lembaga keuangan baik bank maupun lembaga keuangan lainnya sangat dibutuhkan oleh masyarakat. Bagi masyarakat umum keberadaan lembaga keuangan akan menjadi tempat untuk menyimpan tabungan dan atau mendapatkan pinjaman. Bagi dunia usaha, lembaga keuangan dapat menjadi sumber modal. Idealnya layanan keuangan dapat tersedia dan dapat diakses oleh seluruh lapisan masyarakat tanpa kecuali sebagai bagian dari instrumen peningkatan kesejahteraan masyarakat. Ketersediaan layanan keuangan yang dapat dikses oleh masyarakat juga merupakan bagian dari upaya mewujudkan keuangan inklusif. Fokus pengabdian adalah pelatihan pemanfaatan teknologi keuangan (Financial Technology/Fintech) pada pengrajin Batik Tulis Kebon Indah Bayat, Klaten. Tujuan akhir yang ingin dicapai adalah meningkatnya rasa percaya diri anggota koperasi untuk mengaplikasikan fintech dan berkeinginan untuk menggunakan. Pelaksanaan pengabdian meliputi beberapa tahap sebagai berikut: Assesment literasi lembaga keuangan dan sumber-sumber pembiayaan, Assesment literasi fintech, Assesment rasa percaya diri dalam penggunaan fintech, Assesment keingian menggunakan fintech. Pengabdian dalam bentuk pelatihan fintech ini menujukkan adanya keberhasilan yang cukup signifikan, yang tercermin pada peningkatan rasa percaya diri dan keinginan untuk menggunakan fintech.
\end{abstract}

Kata kunci:3-5 kata kunci, Finctech, Assesment literasi fintech, Assesment rasa percaya diri

\section{PENDAHULUAN}

Sektor jasa keuangan memiliki peran yang sangat signifikan dalam pembangunan ekonomi yang bertujuan meningkatkan kesejahteraan bangsa. Keberadaan lembaga keuangan, baik bank maupun lembaga keuangan lainnya sangat dibutuhkan oleh masyarakat. Selain mendukung kegiatan ekonomi, keberadaan bank dan lembaga keuangan lainnya mempermudah masyarakat untuk mendapatkan layanan keuangan. Bagi masyarakat umum keberadaan lembaga keuangan akan menjadi tempat untuk menyimpan tabungan dan atau mendapatkan pinjaman. Bagi dunia usaha, lembaga keuangan dapat menjadi sumber modal. Oleh karena itu, idealnya layanan keuangan tersedia dan dapat diakses oleh seluruh lapisan masyarakat tanpa kecuali sebagai bagian dari isntrumen peningkatan kesejahteraan masyarakat. Ketersediaan layanan keuangan yang dapat diakses oleh masyarakat juga merupakan bagian dari upaya mewujudkan keuangan inklusif (Widiyanto, 2014; Bholat dan Atz, 2016)

UMKM adalah salah satu sektor ekonomi dengan peran besar terhadap perekonomian. Data BPS menunjukkan, sebanyak 99,9 persen unit usaha di Indonesia termasuk kategori UMKM, menyumbang sebesar sekitar 57 persen terhadap PDB dan menyerap tanaga kerja sekitar 97 persen (www.bps.go.id). UMKM merupakan bagian dari pelaku ekonomi yang masuk pada era revolusi industri 4.0, era yang ditandai dengan digitalisasi, otomasi, internet of things (IoT), dan kecerdasan buatan. Kondisi ini pada gilirannya akan menciptakan peluang baru bagi UMKM. Dengan teknologi digital, hambatan-hambatan aktivitas konvensional teratasi (Claessens dan Erik, 2016; Gomber, Koch, dan Siering, 2017; Guild, 2017)

Beberapa penelitian menunjukkan bahwa keuangan inklusif berpengaruh terhadap pengentasan kemiskinan dan pemerataan pendapatan. Namun demikian, implementasinya di Indonesia masih relatif rendah (Chen dan Brono, 2018; Schindler, 2017; Arner, Barberis dan Buckley, 2015). Data Bank Dunia, penduduk Indonesia yang menggunakan jasa keuangan formal masih relatif rendah, yakni pada kisaran 36 persen. Mayoritas penduduk belum terlayani oleh lembaga keuangan formal. Data BPS menunjukkan rasio penghimpunan dana terhadap Produk Domestik Bruto (PDB) adalah sebesar 45 persen, namun dana yang tersalur pada usaha mikro kecil (UMKM) dan menengah hanya sebesar 8 persen. Survei yang dilakukan oleh 
Financial Inclusion insight menunjukkan bahwa orang miskin yang memiliki/pernah memiliki kredit 2.5 persen. Kesulitan mengakses lembaga keuangan formal ini diduga menyebabkan banyak orang miskin yang mengambil pinjaman dari renternir/tengkulak (Hendar, 2014)

Koperasi "Batik Tulis Kebon Indah" di Kecamatan Bayat Kabupaten Klaten merupakan koperasi yang dibentuk pada tahun 2009 dengan jumlah anggota mula-mula 169 orang. Dengan dukungan sebuah lembaga donor, perkumpulan para pembatik memperoleh pembekalan teknis manajerial, pembukuan maupun administrasi keuangan. Mereka juga berlatih untuk memasarkan karyanya sendiri. Koperasi ini di pimpin oleh Ibu Dalmini. Saat ini, jumlah anggota koperasi tersebut mencapai 189 orang. Pada dasarnya koperasi ini telah mengalami kemajuan yang pesat dan cukup dikenal. Namun, saat dilakukan prasurvei terkait dengan digitalisasi UMKM, banyak anggota koperasi yang ingin mengetahui lebih banyak teknologi digital diantaranya adalah pemanfataan teknologi keuangan (financial Technology/Fintech dan Pemasaran Digital (Digital Marketing).

\section{METODE PENGABDIAN}

Fokus pengabdian ini adalah mengenai pelatihan pemanfaatan teknologi keuangan (Financial Technology/Fintech). Tujuan akhir yang ingin dicapai adalah meningkatnya rasa percaya diri anggota koperasi untuk mengaplikasikan fintech dan berkeinginan untuk menggunakan. Pelaksanaan pengabdian meliputi beberapa tahap sebagai berikut:

1. Assesment literasi lembaga keuangan dan sumber-sumber pembiayaan

2. Assesment literasi fintech

3. Assesment rasa percaya diri dalam penggunaan fintech

4. Assesment keingian menggunakan fintech.

\section{HASIL DAN PEMBAHASAN}

\subsection{Profil Perserta Pelatihan}

Jumlah peserta pelatihan pemanfaatan fintech sebayak 30 orang pembatik dengan profil sebagai berikut:

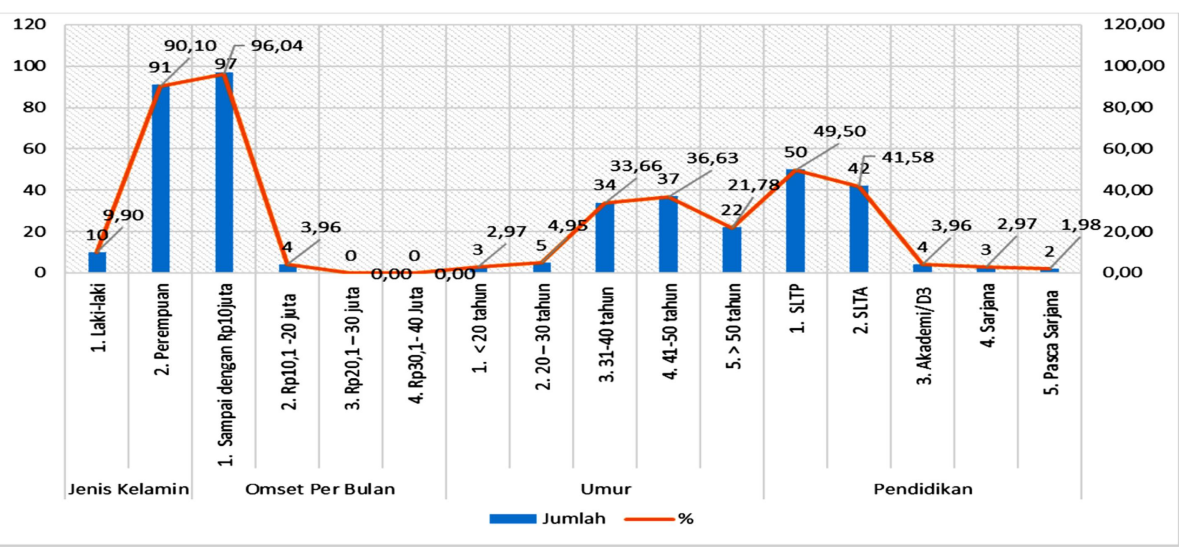

Gambar 1. Profil Peserta Pelatihan 


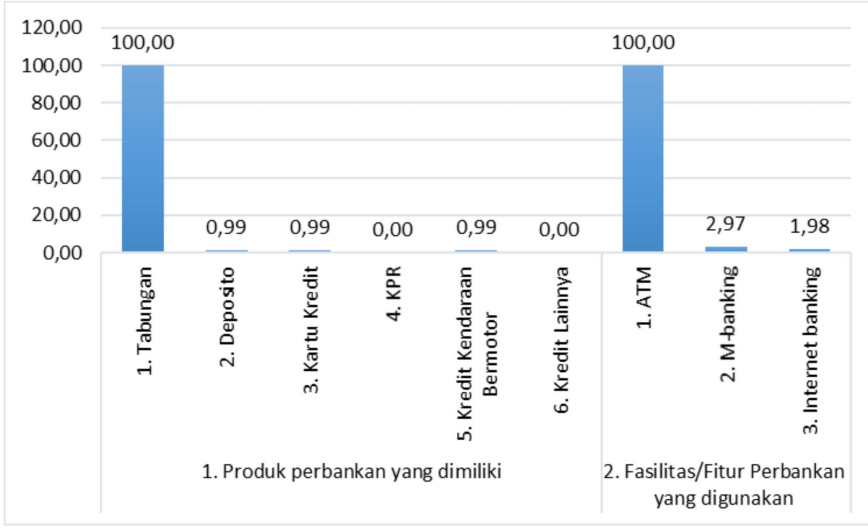

Gambar 2. Produk dan Fasilitas Perbankan yang dimiliki

\subsection{Assesment Literasi Lembaga Keuangan}

Peserta pelatihan telah memiliki pengetahuan yang tinggi mengenai lembaga keuangan bank. Secara lisan, ketika ditanya mengenai lembaga keuangan apa yang diketahui, semua peserta pelatihan menyebutkan bank sebagai jawaban pertama. Artinya, Bank merupakan Top of Mind jenis lembaga keuangan yang diketahui oleh perserta pelatihan. Namun demikian, ketika lebih dalam dirinci menurut jenis bank, tidak semua perserta mengetahuinya (gambar 3).

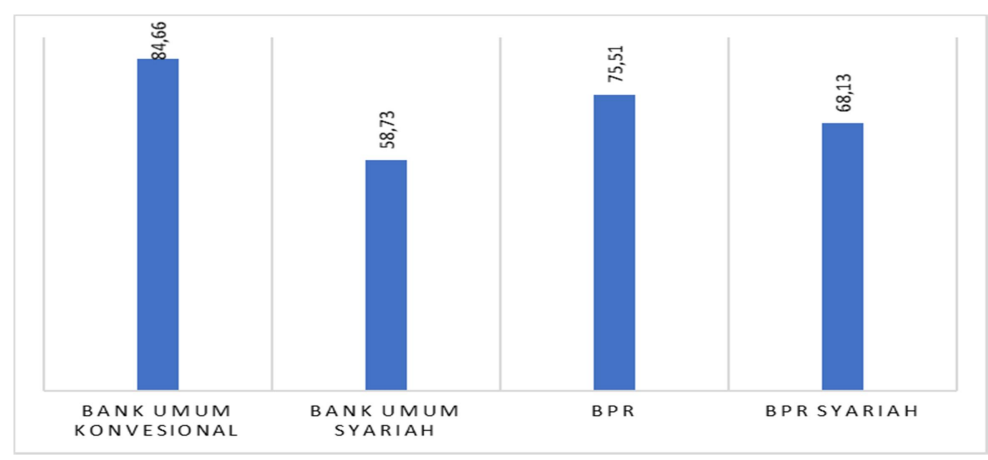

Gambar 3 Jumlah Peserta yang Mengetahui Jenis Bank (\%)

Mengenai jenis lembaga keuangan non bank yang diketahui oleh perserta antara lain:

\begin{tabular}{|l|r|r|c|}
\hline Lembaga Keuangan Non-bank & Tidak Tahu & Ragu ragu & Tahu \\
\hline Dana Pensiun & 33,66 & 1,77 & 64,57 \\
\hline Pasar Modal & 86,14 & 1,09 & 12,77 \\
\hline Pegadaian & 2,97 & 3,86 & 93,17 \\
\hline Lembaga Keuangan Mikro & 24,75 & 2,77 & 72,48 \\
\hline Perusahaan Penjaminan & 57,4 & 1,78 & 40,82 \\
\hline Lain-lain & 86,21 & 1,39 & 12,40 \\
\hline
\end{tabular}

Tabel 1. Tingkat Pengetahuan Jenis Keuangan Non-Bank (\%)

\begin{tabular}{|l|r|r|r|}
\hline Ketrampilan Menghitung & Kurang Trampil & Cukup Trampil & Trampil \\
\hline Bunga/bagi hasil & 32,67 & 57,43 & 9,9 \\
\hline Angsuran/pinjaman & 21,78 & 67,33 & 10,89 \\
\hline
\end{tabular}




\begin{tabular}{|l|r|r|r|}
\hline Hasil Investasi & 38,61 & 53,47 & 7,92 \\
\hline Biaya Penggunaan produk/jasa & 38,61 & 52,48 & 8,91 \\
\hline layanan & 58,42 & 33,66 & 7,92 \\
\hline Denda & 56,44 & 35,64 & 7,92 \\
\hline Perbedaan nilai mata uang & 74,26 & 19,8 & 5,94 \\
\hline Inflasi & 75,25 & 18,81 & 5,94 \\
\hline
\end{tabular}

Tabel 2. Tingkat Ketrampilam Menghitung Keuangan Non-Bank (\%)

\subsection{Assesment Literasi Fintech}

Tingkat awareness dan pengetahuan responden terhadap istilah-istilah dalam fintech atau layanan keuangan digital (LKD) relatif rendah. Dari beberapa istilah yang terkait dengan fintech seperti LKD, e-money, mobile banking, internet banking dan LAKU PANDAI, hanya istilah Mobile Banking/M-banking yang diketahui. Assesment pengetahuan fintech menunjukkan bahwa hanya istilah M-banking yang cukup banyak dikatahui. Selebihnya tidak diketahui. Gambar berikut ini menujukkan persentase jumlah peserta yang tidak mengetahui/merasa belum pernah mendengar istilah-istilah terkait fintech.

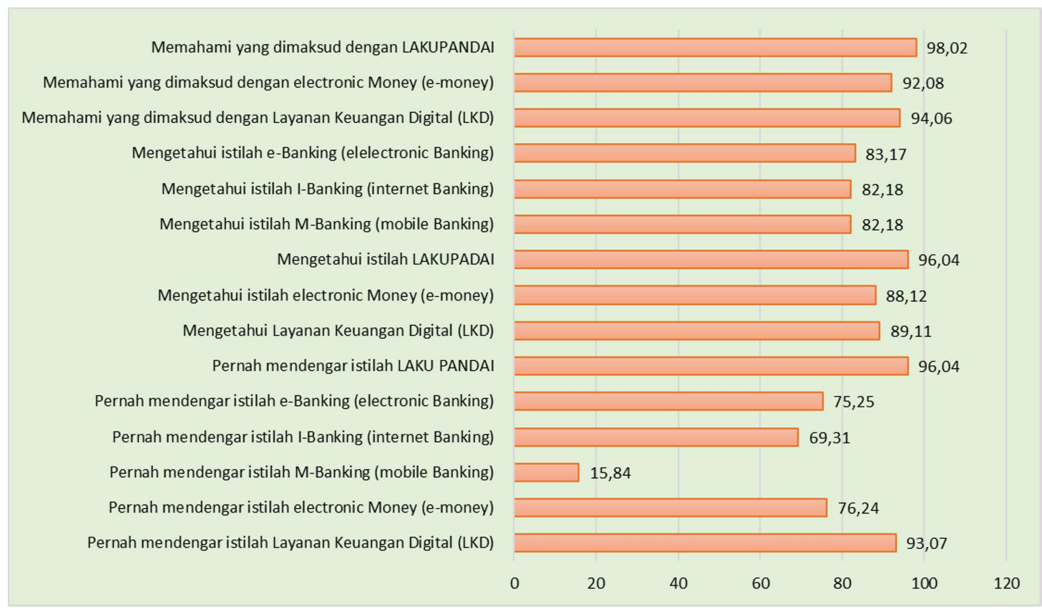

Gambar 4. Persentase Peserta yang Merasa tidak/belum pernah Mendengar Istilah terkait Fintech

Sementara itu, jenis e-money yang banyak diketahui adalah $e$-toll (gambar 5).

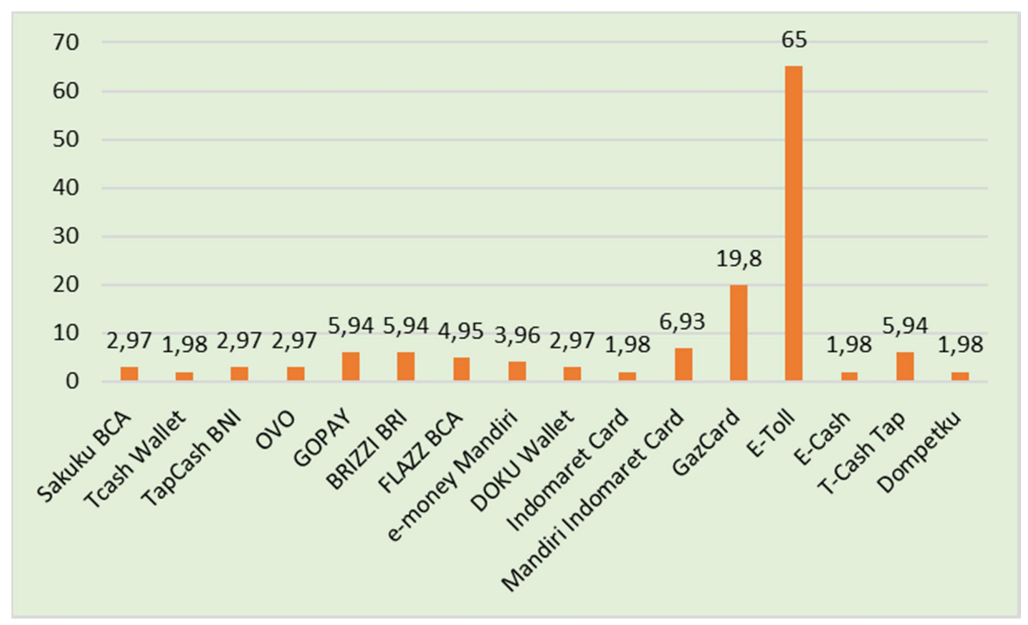

Gambar 5. Jumlah Peserta yang Mengetahui Jenis Bank (\%) 
Mengenai jenis lembaga keuangan non bank yang diketahui oleh perserta antara lain:

\begin{tabular}{|l|r|r|l|}
\hline Lembaga Keuangan Non-bank & Tidak Tahu & Ragu ragu & Tahu \\
\hline Dana Pensiun & 33,66 & 1,77 & 64,57 \\
\hline Pasar Modal & 86,14 & 1,09 & 12,77 \\
\hline Pegadaian & 2,97 & 3,86 & 93,17 \\
\hline Lembaga Keuangan Mikro & 24,75 & 2,77 & 72,48 \\
\hline Perusahaan Penjaminan & 57,4 & 1,78 & 40,82 \\
\hline Lain-lain & 86,21 & 1,39 & 12,40 \\
\hline
\end{tabular}

Tabel 3. Tingkat Pengetahuan Jenis Keuangan Non-Bank (\%)

\begin{tabular}{|l|r|r|r|}
\hline Ketrampilan Menghitung & Kurang Trampil & Cukup Trampil & Trampil \\
\hline Bunga/bagi hasil & 32,67 & 57,43 & 9,9 \\
\hline Angsuran/pinjaman & 21,78 & 67,33 & 10,89 \\
\hline Hasil Investasi & 38,61 & 53,47 & 7,92 \\
\hline Biaya Penggunaan produk/jasa & 38,61 & 52,48 & 8,91 \\
\hline layanan & 58,42 & 33,66 & 7,92 \\
\hline Denda & 56,44 & 35,64 & 7,92 \\
\hline Perbedaan nilai mata uang & 74,26 & 19,8 & 5,94 \\
\hline Inflasi & 75,25 & 18,81 & 5,94 \\
\hline
\end{tabular}

Tabel 4. Tingkat Ketrampilan Menghitung Keuangan Non-Bank (\%)

\subsection{Tahap Perlakuan}

Pelatihan dilakukan dengan menggunakan media power poin dengan presentasi tatap muka beberapa kali tatap muka. Selain memberi pengayaan materi mengenai digitalisasi UMKM dan fintech untuk UMKM, pelatihan juga mencakup cara mengunduh dan menginstal aplikasi dan cara menggunakan aplikasi.
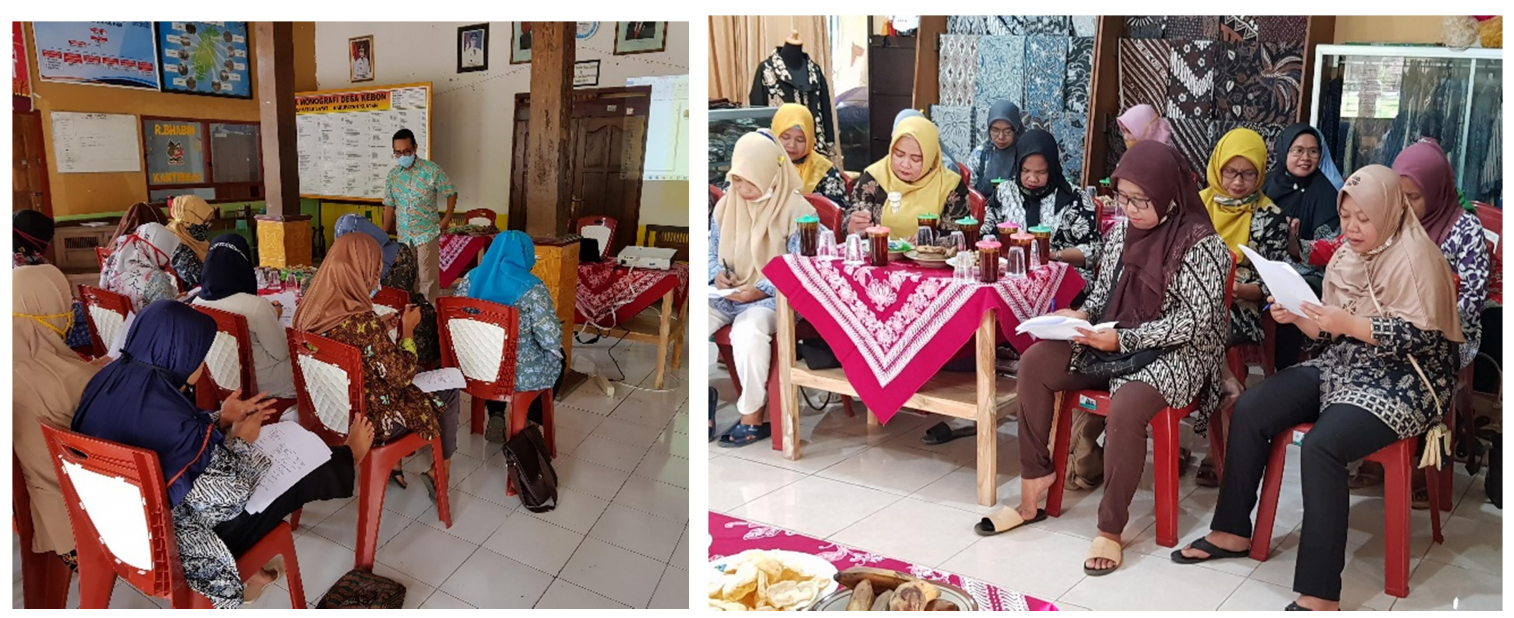

Gambar 6. Assesment Literasi Lembaga Keuangan dan Fintech (Sebelum perlakuan) 

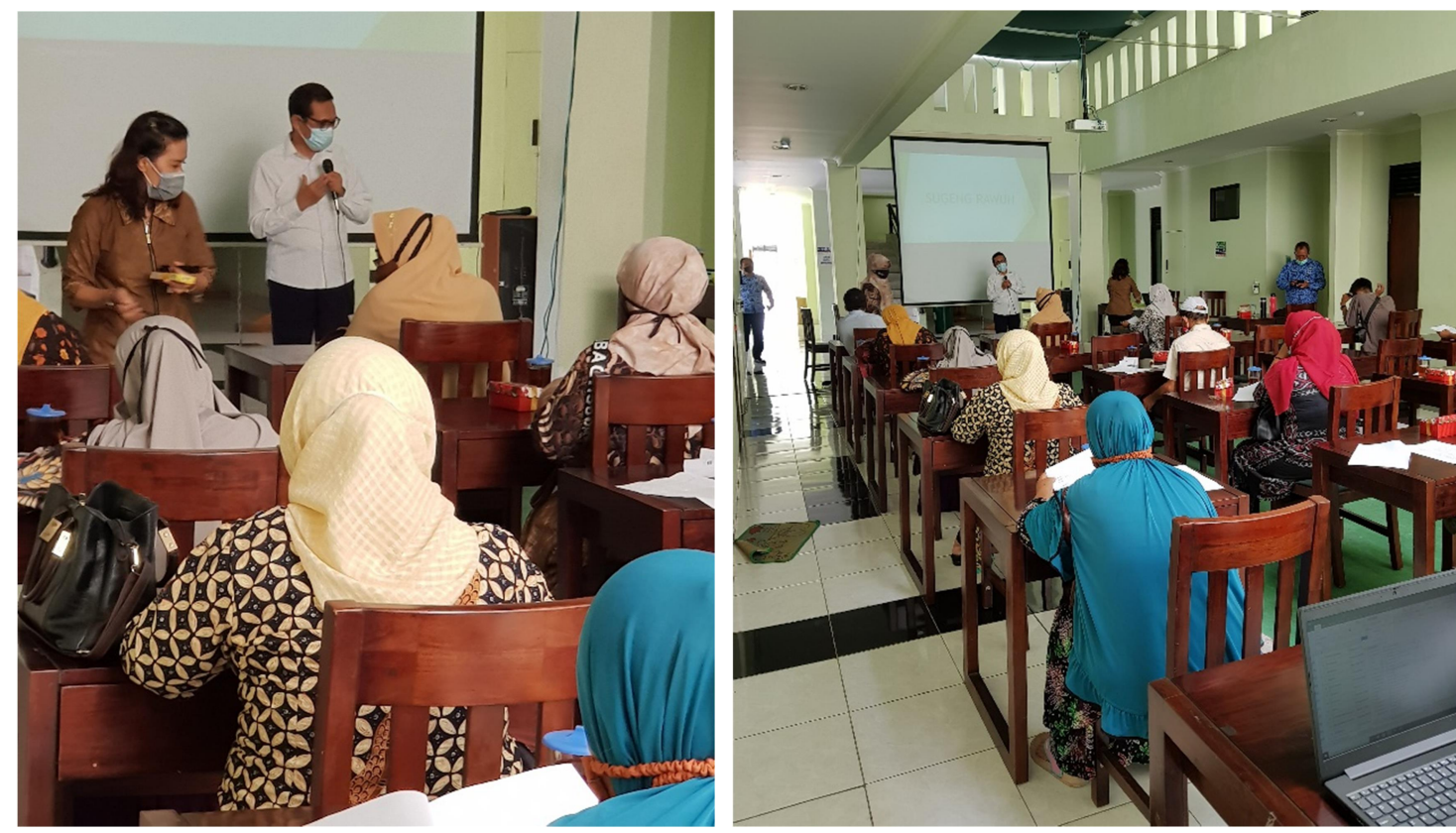

Gambar 7. Assesment Literasi Lembaga Keuangan dan Fintech (Sesudah Perlakuan)

\subsection{Assesment Rasa Percaya Diri dan Keinginan Untuk Menggunakan LKD}

Setelah dilakukan perlakukan dalam beberapa kali terhadap kelompok sasaran diketahui adanya peningkatan rasa percaya diri terkait dengan penggunaan fintech. Hal tersebut tercermin pada hasil assesment mengenai keyakinan keamanan, kemudahan, kecepatan menggunakan fintech. Dapat dilihat pada gambar 7, nilai rata-rata keyakinan pada masing-masing unsur yang ditanyakan setelah mengalami perlakuan lebih tinggi dibanding sebelum perlakuan.

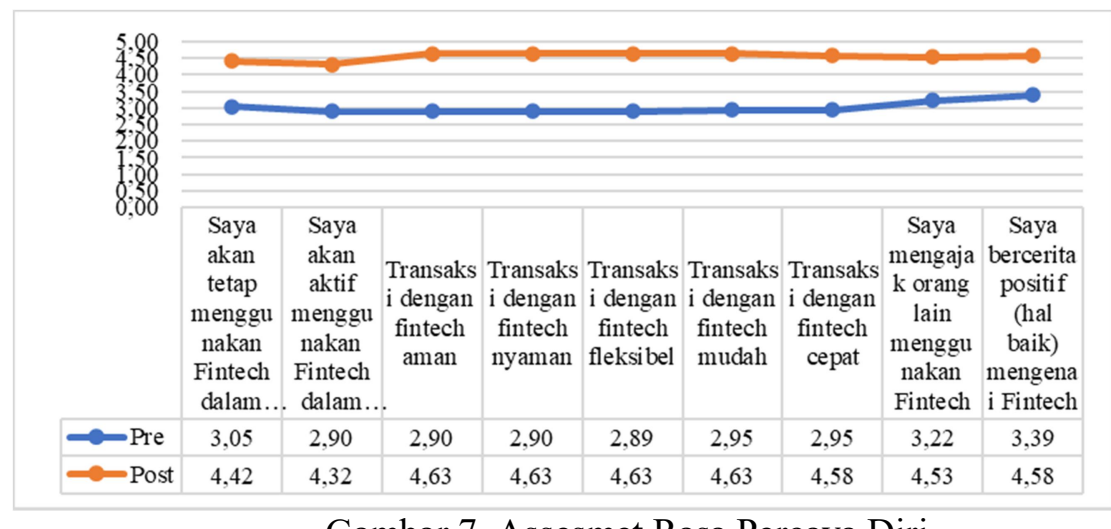

Gambar 7. Assesmet Rasa Percaya Diri

Mereka yang pada saat perlakuan telah menggunakan fintech juga memiliki keiginan menggunakan fintech yang semakin tinggi. Hal tersebut tercermin pada hasil assesment yang disajikan pada gambar 8 . 


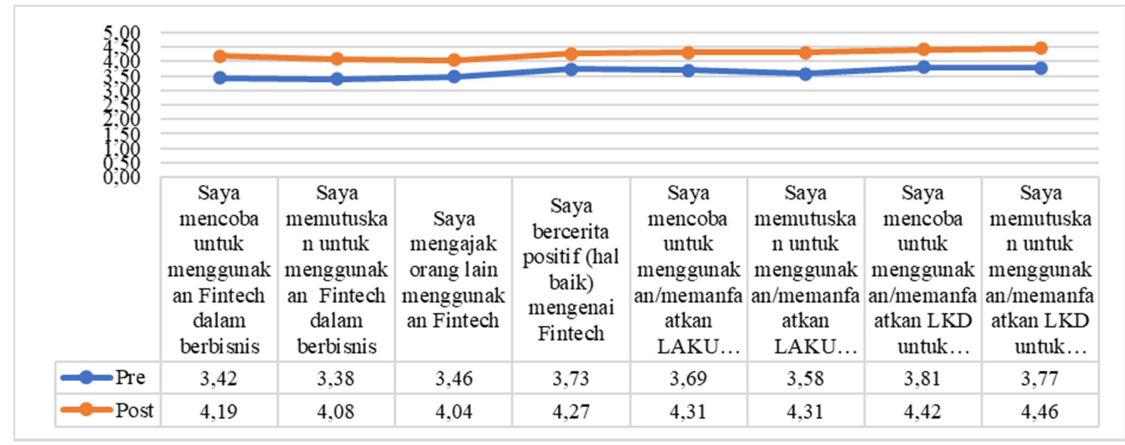

Gambar 8. Keinginan Menggunakan LKD

\section{SIMPULAN}

Pengabdian dalam bentuk pelatihan fintech ini menjukkan adanya keberhasilan yang cukup signifikan. Hal tersebut tercermin pada peningkatan rasa percaya diri dan keinginan untuk menggunakan fintech. Selain itu, terdapat beberapa peserta yang langsung berdiskusi mengenai cara-cara memasang aplikasi fintech dan mengenai bagaimana cara mengaktifkan mobile banking.

\section{SARAN}

Permasalahan digitalisasi UMKM tidak hanya terkait dengan pemanfaatan fintech. Tetapi jauh lebih luas dari hal tersebut. Pelatihan mengenai pemasaran digital merupakan pelatihan yang sangat dibutuhkan oleh UMKM.

\section{UCAPAN TERIMA KASIH}

Penulis mengucapkan terima kasih kepada LPPM Universitas Dian Nuswantoro yang telah memberi dukungan terhadap keberhasilan pengabdian ini. Kepada Bappeda Kabupaten Klaten dan Ibu-ibu Pengrajin Batik Tulis Kebon Indah Bayat Klaten, kami juga mengucapkan terima kasih atas kerjasama dan dukungan kegiatan ini. 


\section{DAFTAR PUSTAKA}

Arner, D. W., Barberis, J. N., \& Buckley, R. P. (1 October 2015). The evolution of FinTech: A new post-crisis paradigm? University of Hong Kong Faculty of Law Research Paper No. 2015/047; UNSW Law Research Paper No. 2016-62.

Bholat, D. M., \& Atz, U. (29 April 2016). Peer-to-peer lending and financial innovation in the United Kingdom. Bank of England Working Paper No. 598.

Chen K., Bruno S. Sergi, "How Can FinTech Impact Russia's Development?" In Exploring the Future of Russia's Economy and Markets. Published online: 22 Oct 2018; 1-11

Claessens, Stijn and Erik Feijen (2016), "Financial sector development and the Millennium Development Goals". World Bank working paper; no. 89

Gomber, P., Koch, J.-A., \& Siering, M. (2017). Digital finance and fintech: Current research and future research directions. Journal of Business Economics, 87(5), 537-580.

Hendrar (2014), Bank Indonesia's Policy on Financial Inclusive through the Non-Cashless National Movement, presented on General Lecture "Kebanksentralan"

Schindler, J. W. (10 August 2017). Fintech and financial innovation: Drivers and depth. Federal Reserve Broad System Working Paper No. 2017-081.

Widianto, B. (2014), Financial Inclusion and Poverty Alleviation, National Team for Acceleration of Poverty Reduction 